\title{
A Brief Study on the Problems and Development Countermeasures of China's International Trade Talents Training
}

\author{
Ruichao Zhang, Hongshan Liu, Jiajing Zhang \\ Beijing Normal University, Beijing, China \\ Email:mlbsabc@sina.com
}

How to cite this paper: Zhang, R.C., Liu, H.S. and Zhang, J.J. (2017) A Brief Study on the Problems and Development Countermeasures of China's International Trade Talents Training. Modern Economy, 8, 1575-1579.

https://doi.org/10.4236/me.2017.812104

Received: November 27, 2017

Accepted: December 17, 2017

Published: December 20, 2017

Copyright $\odot 2017$ by authors and Scientific Research Publishing Inc. This work is licensed under the Creative Commons Attribution International License (CC BY 4.0).

http://creativecommons.org/licenses/by/4.0/

\begin{abstract}
Since the 1990s, it gradually becomes a new approach in the field of international economics to study trade activities from the perspective of human resources. Many scholars believe that the gap of income inequality between two countries increasing or decreasing depends on the trade pattern between the two countries, but in the final analysis, it depends on the state of human capital allocation in both countries. Therefore, human resources are of great significance to the international trade. With China's opening-up policy to the outside world becoming deeper and deeper, there is an increasing demand for international trade talents, and the skilled talents in international economic and trade fields have become scarce talents. However, at present, many universities' international trade graduates find it difficult to get employed, and companies just lack talents in that fields. The main reason for this phenomenon is that the international trade talents trained in colleges and universities are out of touch with the social needs, which caused the phenomenon that graduates majored in international trade can't be used by companies and companies lack talents in the field of international trade but dare not employ the graduates. To study this phenomenon, this paper finds that the teaching objective is not clear in colleges and universities; most colleges and universities pay much attention to theoretical teaching instead of practical teaching and lack teacher allocation. What's more, the curriculum is not reasonable enough. So the colleges and universities should take some measures; they should cultivate talents to be familiar with international business processes and specific operations, international trade negotiation and communication skills, and to be familiar with international trade laws and practices. They also should guide students to get some professional certificates.
\end{abstract}

\section{Keywords}

International Trade, Human Resources, Problems 


\section{Introduction}

International trade refers to the exchange of goods and services in various countries (or regions) of the world. It is the main form of interconnection between countries (or regions) on the basis of international division of Labour. It reflects the economic interdependence of countries (or regions) around the world and it is made up of the sum of foreign trades. With the rapid development of the global economy, China's international trade has encountered new opportunities and challenges. At present, the global economic integration pattern has been preliminarily completed, and China's position in the world international trade area gradually ascends and comprehensive national strength is also gradually enhanced. However, due to the restriction of industrial structure, industrial technology and other aspects, China's international trade still has a lot of space to develop, which can't be done without the training of international trade talents. Since there is not much research about this, therefore, we need to study the problems existing in the training mode of college and universities' international trade talents and actively seek effective improvement measures in order to provide the skilled talents needed by companies for the development of China's international trade.

\section{Problems Existing in the Cultivation of International Trade Talents in Colleges and Universities}

\subsection{The Teaching Objective Is Not Clear and the Talent Supply and Demand Are Out of Touch}

For a long time, China's international trade majors have formed a teaching situation that is disjointed by theory and practice, the disconnection between school and society, the disconnection between teaching and application, and the disconnection of knowledge and skills. If graduates are not qualified for post work, companies are not willing to take the time to conduct pre-job training. This can result in the phenomenon that graduates majored in international trade can't be used by companies and companies lack talents in the field of international trade but dare not employ the graduates [1].

\subsection{Most Colleges and Universities Pay Much Attention to Theoretical Teaching Instead of Practical Teaching}

This is mainly reflected in two aspects. On the one hand, in the aspect of the course and the credit allocation, the practice course occupies a small proportion. On the other hand, even the quantity of courses and hours of practice are guaranteed, in the course of teaching, teachers still pay much attention to books and theories, what's worse, some teachers even don't have international trade experience themselves. Thus, students have poor practical skills.

\subsection{Lack of Teacher Allocation in Colleges and Universities}

At present, many colleges and universities are carrying out bilingual teaching. 
But there is a shortage of teachers who can implement bilingual education, especially in some colleges which are not famous. There are very few teachers who are both proficient in a major and in a foreign language. And the bilingual textbooks suitable for Chinese students are severely deficient. It will be a great challenge for a teacher if he or she teaches in the original textbook, and it is also very difficult for students to digest the material. Therefore, bilingual teaching has raised higher requirements for bilingual teachers [2].

\subsection{The Curriculum Is Not Reasonable Enough}

First, the system and completeness of theories are paid too much attention to. People set curriculum as much knowledge as they can include. The proportion of general courses is too large and occupies some space of specialized courses. The curriculum includes much knowledge, but some specialized courses have not enough knowledge. This leads to a phenomenon that students get a broad field of knowledge but master none. Secondly, through the analysis of international trade textbooks, we can find that there are many knowledge points overlapping. For example, International Trade Practices and Rules, International Business Law and International Trade Affairs have some repetition in aspects of trade terms and freight, insurance and customs.

\section{The Training Direction of International Trade Talents}

\subsection{Cultivate Talents to Be Familiar with International Business Processes and Specific Operations}

According to the online survey and the campus job fair in the past years, many recruitment units, such as foreign trade companies, customs, logistics companies and government foreign trade institutions, etc. require the applicants to be familiar with international business processes and specific operations [3]. This requires that colleges and universities should focus on cultivating students' good application abilities in international business processes, computer office applications, various documents production and document processing.

\subsection{Cultivate Talents to Be Familiar with International Trade Negotiation and Communication Skills}

With the further development of China's socialist market economy, the deepening of the reform of enterprises system and the degree of docking with the world economy, the business negotiation has become the important business content in all kinds of industrial and commercial enterprises' cooperation, development and sale activities [4]. The business or trade major students urgently need to master the negotiation knowledge and skills, and improve the skills continually on the basis of previous experience and lessons. Therefore, college and universities should make their students to learn the international trade negotiation and communication skills systematically and practically. 


\subsection{Cultivate Talents Who Are Familiar with International Trade Laws and Practices}

The trading process of international trade follows the international trade laws and practices. Due to the lack of familiarity with international trade laws and practices, there are many cases of economic loss or even bankruptcy. Especially in the import and export trade between developing countries and developed countries, various laws have become the tools to prevent the import-export trade of a country [5]. So colleges and universities should cultivate students majored in international trade to be familiar with international trade laws and practices.

\subsection{Train International Trade Talents to Be Qualified}

For international trade talents, specific qualified certifications almost become the premise of getting a suitable job. However, there are many qualifications to choose from, and it's impossible for students to apply for each certificate. And the requirements of different positions for certificates are different in some point. As a result, how to organize the student to apply for an examination for a certificate becomes extremely important. So colleges and universities should give students adequate guidance in this regard [6].

For example, if some students want to pay much attention to international trade negotiation or communication, they can take the examination of Business English Certificate (BEC). Or if some students want to be a document specialist in the future or want to know more about international logistics, teachers could recommend some related certificate to the students, so that they will be more qualified for their future career after graduating from colleges or universities.

Besides, international trade talents should also master a foreign language and keep up with the development of global economy.

\section{Conclusion}

In conclusion, there are many problems existing in the cultivation of international trade talents in colleges and universities. The teaching objective is not clear and the talent supply and demand are out of touch. Most colleges and universities pay much attention to theoretical teaching instead of practical teaching. There is a lack of teacher allocation in colleges and universities. And the curriculum is not reasonable enough. Besides, we also talked the training direction of international trade talents. So colleges and universities should take corresponding measures to cultivate the skilled international trade talents that the foreign trade enterprises really need. Considering the problems, it is beyond question that excellent and stable teachers' team is an important guarantee of excellent talent training [7]. Apart from improving the treatment of teachers and strengthening the management of normal teaching order, colleges and universities should also provide a relatively liberal teaching environment for teachers in order to release the teacher's personal inspiration and wisdom to a greater extent. As to the major of international trade, on the one hand, we should strengthen 
the practice ability of teachers. For example, in terms of teacher management system, the colleges and universities can arrange some excellent teachers to attend various training outside the school. Colleges and university leaders should also encourage some outstanding and professional teachers to go out and study in other schools and to practice and exercise in foreign trade enterprises with the aim of improving teachers' overall practical ability. On the other hand, colleges and universities also should improve the bilingual teaching level of teachers [8]. In the course of teaching, colleges and universities could appropriately increase the income of bilingual teachers, add teachers' learning opportunities or take other measures to encourage teachers to actively explore bilingual teaching. Colleges and universities could also hire scholars who have studied abroad to serve as bilingual teachers, or introduce some foreign trade experts to train teachers of that major or even let them take some appropriate course or appropriate proportion of the teaching tasks.

\section{References}

[1] Zhang, J. (2008) The Exploration of Cultivating the Training Mode of Application-Oriented International Trade Professionals. Management, 5, 13-18.

[2] Wu, Y. and Tan, L.W. (2004) Study on Transnational Mergers and Acquisitions of Chinese Enterprises. Exploration of Economic Problems, No. 8, 2-6.

[3] Ni, Y. (2006) Study on the International Trade Practice under the Condition of Informatization in China. Information Science, 24, 1481-1485.

[4] Gandolfo, G. (2014) International Trade. 3rd Edition, International Trade Theory and Policy, Springer-Verlag, Berlin Heidelberg.

[5] Depken II, C.A. and Sonora, R.J. (2005) Asymmetric Effects of Economic Freedom on International Trade Flows. International Journal of Business and Economics, 4, 141-155.

[6] Francois, J.F., Miriam, M. and Martin, W. (2012) Market Structure in CGE Model of International Trade. In: Dixon, P. and Jorgenson, D., Eds., Handbook of Computable General Equilibrium Modeling, Elsevier, Amsterdam.

[7] Ju, J. and Krishna, K. (2005) Welfare and Market Access Effect of Piecemeal Tariff Reform. Journal of International Economics, 51, 305-316. https://doi.org/10.1016/S0022-1996(99)00024-0

[8] Lin, Y.J., Wang, Z.Q. and Li, M.L. (2013) Executive Change and Earnings Management-Empirical Research Based on Accrual Project Manipulation and Real Activity Manipulation. Nankai Business Review, No. 1, 4-14. 